\title{
DAN BARTHOLOMEW AND THE FAIR CHÂTELAINE
}

EVEN hundred years ago, in a castle not twenty
miles from Canterbury, there lived a very vain the manor and was known from Oxford to Jerusalemwherever there were knights to joust for her and minstrels to sing of her - as the Fair Châtelaine. And there was also, tucked away in a little cell under the castle leads, a very holy old priest called Dan Bartholomew, who said Mass for the inmates of the castle and did his best to look after their souls.

This was no light task. For though the lord of the castle was a pious enough man when he was at home (which was not often), and the poor peasants round about found time between dawn and dusk to say a few prayers and light a few candles in the forlorn little chapel by the gate-house, the lady kept as far as she could from prayer and altogether from penance. Yet certainly few people needed penance more than that worldly dame. Never a year went by but she spent a knight's ransom in clothes; and the older she got and the more her beauty waned, the more new-fangled and costly became her attire.

Of course in her husband's absence it was Dan Bartholomew's business to check her; but she was like the crab which when asked why it walked sideways said, " So I learnt from my parents," and gave him nothing but saucy answers in return for his serious admonitions. When her husband came back from the Crusade it was even worse. For though he told her she looked more like a knight of the Round Table than an honest woman, with her peaked shoes and parti-coloured surcoat, he had evidently thought of nothing else but her adornment all the way home. 


\section{Blackfriars}

Two long-eared mules stood among his war-horses in the courtyard; and when they were unloaded there was bale of red tissue from Tripolis and two of samite (as velvety as a white rose-petal) from Venice, and from Paris a length of that very green cloth which St. Louis refused to wear because it was so expensive -not to mention jewelled hair-nets and dragonheaded belts, and rings and trinkets innumerable.

As soon as her husband had gone away again-this time to the Welsh Marches, which had nothing like the same interest for the Fair Chattelaine as the Holy Land-she set to work to make up and wear her new clothes. And of course she filled the whole castle with a merry company of minstrels and ladies, for there would have been no satisfaction whatever in donning her finery alone. And all this while Dan Bartholomew in his hot little cell under the leadsfor it was high midsummer and sultry at that-was fasting and praying and calling on all the saints in the calendar to help him to check her pride and foolhardiness. He saw very little of her himself except at meals, when he said grace for the whole company and wondered, as the courses went round, what each of the guests would look like on the Last Day-as one often does oneself in a railway carriage. And on Sunday when the whole cortège turned up in his damp little chapel to get through the very minimum of religion that was to keep them out of the wrath of God and man, he wondered still more.

I don't quite know how it first occurred to Dan Bartholomew to match his wits as well as his prayers and good works against the frivolity of the Fair Châtelaine, but I think it was after he came back from the Chapter at Canterbury and heard, among other ecclesiastical intelligence, what the Chancellor of the University of Paris had said about the tongued and slashed dresses of the women of Paris. It was 


\section{Dan Bartholomew and the Fair Châtelaine}

those long tails of cut cloth which dangled from their waists like ribbons from a maypole that had moved the Chancellor to such eloquence. "The devil was content with one tail," he said bitterly, "and that behind. But these fashionable dames had tails ad circumferentiam, all the way round!" This story amused Dan Bartholomew, and he had a very shrewd idea that it would amuse the Fair Châtelaine, who was not by any means slow to see a joke. And then it dawned upon him, to his great confusion, that he had never tried to turn her own weapons against her, which ever since David threw away his catapult and used Goliath's sword on that giant's own head, has been the best way of dealing with a tough foe. So next Sunday when the Fair Châtelaine entered his little chapel with a white train the length of your arm-which excited great interest and admiration among the half-starved serfs in the rear-he did not speak out then and there, when she could have had no chance of answering back, but waited until dinner was over the next day to relate the following story.

"I once heard tell of a certain woman who used to trail a white garment on the ground behind her, and leave a cloud of dust in her wake, up to the very image of the Crucified or even to the altar itself. One wet Sunday as she came out into the church porch she threw her train over her arm on account of the mud; and as she did so a certain holy man saw a devil, who was standing by enjoying the sight, laugh with considerable heartiness.

"'What makes you laugh so merrily?' said the holy man. And the devil answered :

"Well, the fact is, one of my colleagues, quidam socius meus, was sitting on that woman's train and using it as his chariot ; but when she threw it over her arm, my colleague fell off in the mud; and that is the reason I laugh so heartily!', 


\section{Blackfriars}

The Fair Châtelaine and her noble company laughed heartily too: and henceforth refused to allow Dan Bartholomew to return to his cell after dinner, but urged him to take his turn at story-telling with the other inmates of the castle ; and at this he gradually became so proficient that what began in jest ended in earnest and little by little the Fair Châtelaine, touched by his courtesy and perseverance, left off her spendthrift ways. She became noted first for her wit, which can at least be indulged in without hurting other people; and last for her piety, which can never be exercised without enriching them: and her long train so far from remaining the chariot of fiends was cut up into a white cope for the Feasts of Virgins and Confessors. And if.(says the chronicler) you think this is an unlikely matter that a soul should be saved by a simple jest, know this : that most people are neither good nor bad of a purpose, but like the unstable bat, which cannot make up its mind to be a beast or a bird, are now one and now the other. And even as a bat, for a piece of bacon or a cake, may be caught under the hat of the pursuer; so, under Providence, a little pleasant enticing will entangle a stray soul until it is safely lodged in the hands of amendment.

Helen Parry Eden. 